\title{
Glycogen Synthase Kinase-3 Beta
}

National Cancer Institute

\section{Source}

National Cancer Institute. Glycogen Synthase Kinase-3 Beta. NCI Thesaurus. Code C128886.

Glycogen synthase kinase-3 beta ( $420 \mathrm{aa}, \sim 47 \mathrm{kDa}$ ) is encoded by the human GSK3B gene. This protein plays a role in both protein phosphorylation and the inhibition of glycogen synthesis. 